\title{
PROFIL DARAH (HEMOGLOBIN DAN HEMATOKRIT) BROILER JANTAN YANG DIBERI Nigella sativa (JINTAN HITAM) SEBAGAI IMUNOMODULATOR
}

\author{
Blood Profile (Hemoglobin And Hematocrit) Of Male Broiler Chicken That Given Nigella Sativa \\ (Black Cumin Seeds) As Immunomodulator
}

\author{
Rizki Tikadewi Noviani, Purnama Edy Santosa, Sri Suharyati, dan Siswanto \\ Departement of Animal Husbandry, Faculty of Agriculture, University of Lampung \\ Jl. Prof. Dr. Soemantri Brojonegoro No.1 Gedong Meneng Bandar Lampung 35145 \\ e-mail: rizukitika@gmail.com
}

\begin{abstract}
The purpose of this study was to determine the description of the blood profile especially hemoglobin and hematocrit of male broiler chickens that given Nigella sativa (black cumin seed). This research was conducted on 18 December 2019-16 January 2020 at the Integrated Field Laboratory, Faculty of Agriculture, Lampung University and Pramitra Biolab Indonesia Clinical Laboratory, Bandarlampung. This study used a completely randomized design (CRD) with 4 treatments and 3 replications. The treatments given in this study were broiler chickens drinking water without Nigella sativa (P0), drinking water with $36 \mathrm{mg} / \mathrm{kg} \mathrm{BW/day} \mathrm{of} \mathrm{Nigella} \mathrm{sativa} \mathrm{(P1),} \mathrm{drinking} \mathrm{water} \mathrm{with} 72 \mathrm{mg} / \mathrm{kg}$ BW/day of Nigella sativa (P2), drinking water with $144 \mathrm{mg} / \mathrm{kg}$ BW/day of Nigella sativa (P3). Data were analyzed descriptively (histogram). The results showed that application of Nigella sativa at a dose of $144 \mathrm{mg} / \mathrm{kg}$ $\mathrm{BW} /$ day (P3) was the optimal dose to increase hemoglobin levels and hematocrit values of male broiler chicken.
\end{abstract}

Keywords: Black cumin, hemoglobin, hematocrit, immunomodulator, male broiler, Nigella sativa

\begin{abstract}
ABSTRAK
Tujuan dari penelitian ini adalah untuk mengetahui gambaran profil darah khususnya hemoglobin dan hematokrit broiler jantan yang diberi Nigella sativa (jintan hitam). Penelitian ini dilaksanakan pada 18 Desember 2019-16 Januari 2020 di Laboratorium Lapang Terpadu, Fakultas Pertanian, Universitas Lampung dan Laboratorium Klinik Pramitra Biolab Indonesia, Bandarlampung. Penelitian ini menggunakan Rancangan Acak Lengkap (RAL) dengan 4 perlakuan dan 3 ulangan. Perlakuan yang diberikan pada penelitian ini yaitu air minum tanpa Nigella sativa (P0), air minum dengan $36 \mathrm{mg} / \mathrm{kg}$ $\mathrm{BB} /$ hari Nigella sativa (P1), air minum dengan $72 \mathrm{mg} / \mathrm{kg} \mathrm{BB} /$ hari Nigella sativa (P2), air minum dengan $144 \mathrm{mg} / \mathrm{kg} \mathrm{BB} /$ hari Nigella sativa (P3). Data dianalisis dengan analisis deskriptif (histogram). Hasil penelitian menunjukkan bahwa pemberian Nigella sativadengan dosis $144 \mathrm{mg} / \mathrm{kg} \mathrm{BB} / \mathrm{hari}$ (P3) merupakan dosis yang optimal untuk meningkatkan kadar hemoglobin dan nilai hematokrit.
\end{abstract}

Kata kunci: Broiler jantan, hemoglobin, hematokrit, imunomodulator, Nigella sativa

\section{PENDAHULUAN}

Peternakan di Indonesia saat ini mengalami perkembangan yang sangat pesat. Perkembangan tersebut digunakan untuk mencukupi kebutuhan daging untuk masyarakat sebagai salah satu sumber protein. Broiler merupakan salah satu jenis ternak yang ideal untuk pemenuhan kebutuhan daging dan mempunyai prospek yang baik. Penggunaan obat-obatan dalam usaha peternakan hampir tidak dapat dihindarkan, karena ternak diharapkan selalu berproduksi secara optimal. Untuk bidang peternakan, pemakaian antibiotika selain pengobatan penyakit, juga digunakan untuk memacu pertumbuhan ternak (growth promotor), yang umumnya ditambahkan dalam pakan sebagai imbuhan. Pada pemakaian antibiotika dalam bidang peternakan, faktor keamanan harus dipertimbangkan, diantaranya adalah keamanan produk peternakan dari residu antibiotika yang digunakan. 
Herbal merupakan tanaman obat alami yang dapat berdampak positif terhadap pertumbuhan dan kekebalan terhadap penyakit. Salah satu upaya untuk menggantikan antibiotika adalah penggunaan Nigella sativa (jintan hitam). Jintan hitam diketahui dapat meningkatkan respons imun pada manusia. Salah satu produk jamu minyak biji jintan hitam yang beredar di Indonesia mampu meningkatkan kemampuan fagositosis sel makrofag, tetapi menekan proliferasi sel limfosit. Imunomodulator adalah semua obat yang dapat memodifikasi respons imun dengan menstimulasi mekanisme pertahanan alamiah dan adaptif, dan dapat berfungsi baik sebagai imunosupresan maupun imunostimulan (Patil et al., 2012).

\begin{abstract}
Pemilihan herbal jintan hitam ini didasarkan pada potensinya sebagai imunomodulator. Imunomodulator merupakan senyawa yang mengubah aktivitas sistem imun tubuh dengan dinamisasi regulasi sel-sel imun seperti sitokin (Spelman et al., 2006). Imunomodulator adalah substansi yang dapat membantu memperbaiki fungsi sistem imun. Secara klinis suatu imunomodulator digunakan pada pasien dengan gangguan imunitas, antara lain pada kasus kanker, HIV/AIDS, malnutrisi, alergi, dan lain-lain. (Bratawidjaja, 2006). Imunomodulator membantu merangsang tubuh memproduksi lebih banyak antibodi dan mengaktifkan sistem kekebalan tubuh agar daya tahan tubuh bekerja optimal sehingga untuk pertumbuhan dan produktivitas dapat berjalan secara maksimal dan memberikan hasil yang optimal.
\end{abstract}

Profil darah adalah salah satu parameter fisiologis tubuh broiler. Untuk melihat peranan jintan hitam sebagai imunomodulator dapat dilihat dari kadar hemoglobin dan nilai hematokrit broiler. Di dalam eritrosit terdapat hemoglobin $(\mathrm{Hb})$ yang mempunyai fungsi penting dalam mengangkut oksigen dari paruparu ke berbagai jaringan tubuh (Sturkie, 1998). Hematokrit merupakan perbandingan antara eritrosit dengan plasma di dalam perifer. Maka dari itu, berhubungan erat sekali bila terjadi penurunan jumlah eritrosit maka akan diikuti oleh penurunan nilai hematokrit (Narendra, 2007). Nilai hematokrit dipengaruhi oleh beberapa faktor, yaitu umur, jenis kelamin, status nutrisi, keadaan hipoksia, keadaan hidrasi, dan ukuran eritrosit (Muchacka et al., 2012).

Selama ini belum ada penelitian tentang pengaruh pemberian Nigella sativa (Jintan hitam) terhadap profil darah (hemoglobin dan hematoktrit) broiler jantan. Oleh karena itu, penting dilakukan penelitian pemberian Nigella sativa (jintan hitam) sebagai imunomodulator terhadap profil darah broiler yang ditinjau dari jumlah hemoglobin dan kadar hematokrit.

\section{BAHAN DAN METODE}

Penelitian ini dilaksanakan pada 18 Desember 2019-16 Januari 2020 di unit kandang Laboratorium Lapang Terpadu, Fakultas Pertanian, Universitas Lampung. Sampel darah penelitian ini dianalisis di Laboratorium Klinik Pramitra Biolab Indonesia, Bandarlampung.

Bahan yang digunakan dalam penelitian ini adalah broiler strain Cobb (CP 707) sebanyak 60 ekor. Penelitian ini dilakukan secara eksperimental menggunakan Rancangan Acak Lengkap (RAL) yang terdiri atas 4 perlakuan dan 3 ulangan. Setiap ulangan terdiri dari 5 ekor. yaitu P0 : air minum tanpa Nigella sativa (jintan hitam), P1 : air minum dengan dosis $36 \mathrm{mg} / \mathrm{kg}$ BB/hari Nigella sativa (jintan hitam), P2 : air minum dengan dosis $72 \mathrm{mg} / \mathrm{kg} \mathrm{BB} /$ hari Nigella sativa (jintan hitam), P3 : air minum dengan dosis $144 \mathrm{mg} / \mathrm{kg} \mathrm{BB} /$ hari Nigella sativa (jintan hitam).

Peubah yang diamati dalam penelitian ini adalah nilai hemaglobin dan kadar hematokrit. Data profil darah (hemoglobin dan hematokrit) dari masing-masing perlakuan dan kontrol disusun dalam bentuk tabulasi sederhana dan dibuat histogram kemudian dianalisis secara deskriptif kuantitatif serta dibandingkan dengan standar fisiologis darah broiler. Analisis deskriptif akan menyajikan rangkuman statistik dalam bentuk tabel dan/grafik serta rangkuman deskriptif untuk beberapa variabel penting untuk menunjukkan pola hubungan antara variabel tujuan (variabel tak-bebas atau variabel akibat) dengan satu atau dua variabel penyebab (variabel bebas) (Syaodi, 2012).

\section{HASIL DAN PEMBAHASAN}

\section{Pengaruh Perlakuan Dosis Jintan Hitam Terhadap Kadar Hemoglobin Broiler Jantan}

Hasil penelitian menunjukkan bahwa pengaruh perlakuan dosis jintan hitam memiliki rata-rata kadar hemoglobin broiler jantan sebagai berikut: P0 $(9,13 \pm 0,31)$; P1 $(9,57 \pm 0,40)$; $\mathbf{P 2}$ $(8,33 \pm 1,08)$; dan P3 $(10,16 \pm 0,86)$ (Tabel 1). Kadar hemoglobin rata-rata tiap perlakuan juga 
terbilang normal karena berada pada kisaran 8,33-10,16 g/dl. Menurut Dharmawan (2002), kadar hemoglobin normal pada ayam berkisar antara 7,0 $\mathrm{g} / \mathrm{dl}-13,0 \mathrm{~g} / \mathrm{dl}$ dengan rata-rata 9,0 $\mathrm{g} / \mathrm{dl}$.

Tabel 1. Rata-rata kadar hemoglobin broiler jantan (g/dl)

\begin{tabular}{ccccc}
\hline Ulangan & \multicolumn{4}{c}{ Perlakuan } \\
\cline { 2 - 5 } & P0 & P1 & P2 & P3 \\
\cline { 2 - 5 } 1 & 9,40 & 9,10 & 7,10 & 10,20 \\
2 & 9,20 & 9,80 & 9,10 & 11,00 \\
3 & 8,80 & 9,80 & 8,80 & 9,30 \\
\hline Jumlah & 27,40 & 28,70 & 25,00 & 30,50 \\
\hline Rata-rata & $9,13 \pm 0,31$ & $9,57 \pm 0,40$ & $8,33 \pm 1,08$ & $10,16 \pm 0,86$ \\
\hline
\end{tabular}

Keterangan:

P0 : air minum tanpa Nigella sativa (jintan hitam);

$\mathrm{P} 1$ : air minum dengan dosis $36 \mathrm{mg} / \mathrm{kg} \mathrm{BB} /$ hari Nigella sativa (jintan hitam);

P2 : air minum dengan dosis $72 \mathrm{mg} / \mathrm{kg} \mathrm{BB} /$ hari Nigella sativa (jintan hitam);

P3 : air minum dengan dosis $144 \mathrm{mg} / \mathrm{kg} \mathrm{BB} /$ hari Nigella sativa (jintan hitam).

Berdasarkan pada Gambar 1, dapat diketahui bahwa broiler dengan pemberian $N$. sativa (jintan hitam) (P3) sebanyak $144 \mathrm{mg} / \mathrm{kg}$ $\mathrm{BB} /$ hari menunjukkan kadar hemoglobin paling tinggi dibandingkan dengan P0 (kontrol), P1 (36 $\mathrm{mg} / \mathrm{kg} \mathrm{BB} /$ hari), dan $\mathrm{P} 2$ (72 $\mathrm{mg} / \mathrm{kg} \mathrm{BB} /$ hari). Semakin tinggi dosis jintan hitam yang diberikan, kadar hemoglobin broiler jantan cenderung naik sampai dosis yang tertinggi. Hal ini diduga karena tingginya kandungan zat nutrisi pada jintan hitam seperti riboflavin, piridoksin, folacin, dan zat besi. Menurut Sudewo (2012), jintan hitam memiliki kandungan zat nutrisi yang tinggi seperti protein, lemak, karbohidrat, tiamin, riboflavin, piridoksin (vitamin B6), niacin, folacin, kalsium, zat besi, seng dan fosfor.

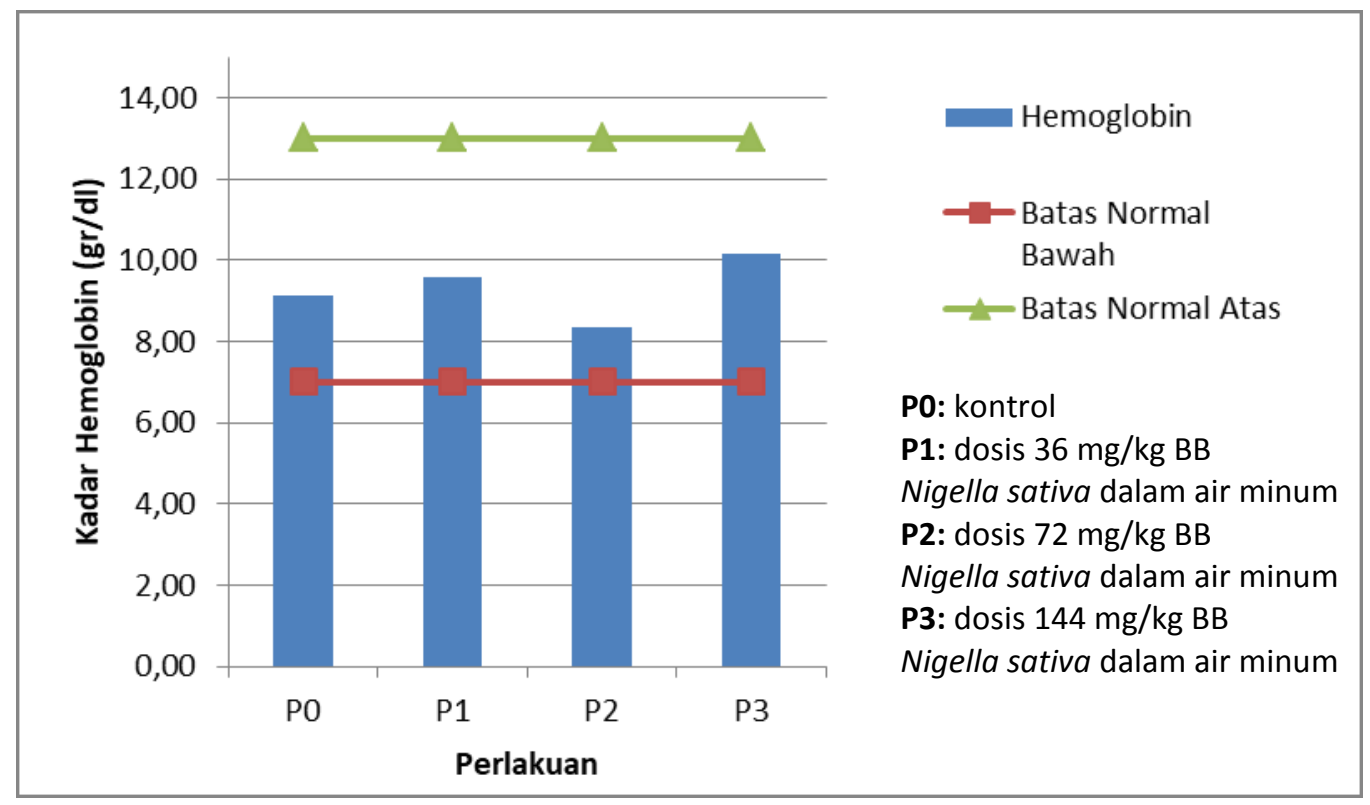

Gambar 1. Rata-rata kadar hemoglobin broiler jantan

Proses eritropoesis tubuh ayam membutuhkan prekusor untuk membentuk sel baru. Prekusor tersebut adalah $\mathrm{Cu}, \mathrm{Fe}$, dan $\mathrm{Zn}$. Serta zat lain seperti pridoksin, riboflavin dan 
vitamin C. Hal ini sesuai dengan pernyataan Praseno (2005), proses pembentukan eritrosit baru setiap harinya membutuhkan prekusor untuk mensintesis sel baru. Prekusor yang dibutuhkan berupa $\mathrm{Cu}, \mathrm{Fe}$, dan $\mathrm{Zn}$. Serta menurut Siswanto (2017), pembentukan eritrosit membutuhkan vitamin B12, piridoksin, riboflavin, nicotinic acid, panthotenic acid, biotin dan vitamin C. Kekurangan zat-zat yang berpengaruh dalam pembentukan eritrosit dapat mengganggu eritropoesis.

\section{Pengaruh Perlakuan Dosis Jintan Hitam Terhadap Jumlah Nilai Hematokrit Broiler Jantan}

Hasil penelitian menunjukkan bahwa perlakuan dosis jintan hitam memiliki rata-rata hematokrit broiler jantan sebagai berikut: P0 (34,67 $\pm 0,93)$; P1 (36,00 $\pm 2,27) ; \mathbf{P 2}(31,03 \pm 3,77)$; dan P3 $(37,07 \pm 2,18)$. Data nilai hematokrit broiler jantan dapat dilihat pada Tabel 2 .

Tabel 2. Rata-rata nilai hematokrit broiler jantan (\%)

\begin{tabular}{ccccc}
\hline \multirow{2}{*}{ Ulangan } & \multicolumn{5}{c}{ Perlakuan } \\
\cline { 2 - 4 } & & P0 & P1 & P2 \\
\hline 1 & 35,10 & 33,40 & 26,70 & 37,40 \\
2 & 35,30 & 37,00 & 33,60 & 39,00 \\
3 & 33,60 & 37,60 & 32,80 & 34,68 \\
\hline Jumlah & 104,00 & 108,00 & 93,10 & 111,08 \\
\hline Rata-rata & $34,67 \pm 0,93$ & $36,00 \pm 2,27$ & $31,03 \pm 3,77$ & $37,07 \pm 2,18$ \\
\hline
\end{tabular}

Keterangan:

P0 : air minum tanpa Nigella sativa (jintan hitam);

P1 : air minum dengan dosis $36 \mathrm{mg} / \mathrm{kg} \mathrm{BB} /$ hari Nigella sativa (jintan hitam);

P2 : air minum dengan dosis $72 \mathrm{mg} / \mathrm{kg} \mathrm{BB} /$ hari Nigella sativa (jintan hitam);

P3 : air minum dengan dosis $144 \mathrm{mg} / \mathrm{kg} \mathrm{BB} /$ hari Nigella sativa (jintan hitam).

Rata-rata nilai hematokrit broiler jantan masing-masing variabel berkisar antara 31,03$37,07 \%$. Angka tersebut termasuk nilai hematokrit yang normal pada ayam. Hal ini sesuai dengan pendapat Samour (2015) yaitu nilai hematokrit merupakan massa sel terbesar dalam darah dengan kisaran normal pada ayam yaitu $24 \%-43 \%$.

Berdasarkan histogram pada Gambar 2, nilai hematokrit pada pemberian $N$. sativa (jintan hitam) dengan dosis $144 \mathrm{mg} / \mathrm{kg}$ BB/hari (P3) menunjukkan nilai hematokrit tertinggi dibandingkan dengan kontrol, P1, dan P2. Hal tersebut menunjukkan bahwa terdapat tren peningkatan dari variabel kontrol sampai P3 yang memiliki dosis yang tinggi. Semakin tinggi dosis yang digunakan nilai hematokrit semakin meningkat.

Kadar hematokrit menunjukkan pula jumlah eritrosit yang ada pada tubuh broiler. Menurut Hoffbrand dan Pettit (1996), hematokrit menunjukan besarnya volume sel darah merah darah. Hematokrit sejatinya merupakan ukuran yang menentukan seberapa banyak jumlah sel darah merah dalam satu milimiter darah atau dengan kata lain perbandingan antara sel darah merah dengan komponen darah lain.

Jumlah eritrosit dan hemoglobin yang berada pada kisaran normal menyebabkan kadar hematokrit juga menjadi normal. Kadar hematokrit sangat tergantung pada jumlah eritrosit karena hematokrit digunakan untuk menentukan seberapa banyak perbandingan jumlah erirosit dengan komponen darah lainnya. Hal ini sesuai dengan pendapat Guyton dan Hall (2006), nilai hematokrit berbanding lurus dengan jumlah eritrosit dan kadar hemoglobin pada kondisi hewan normal sehingga meningkatnya jumlah eritrosit dapat mengindikasikan terjadinya peningkatan nilai hematokrit. 


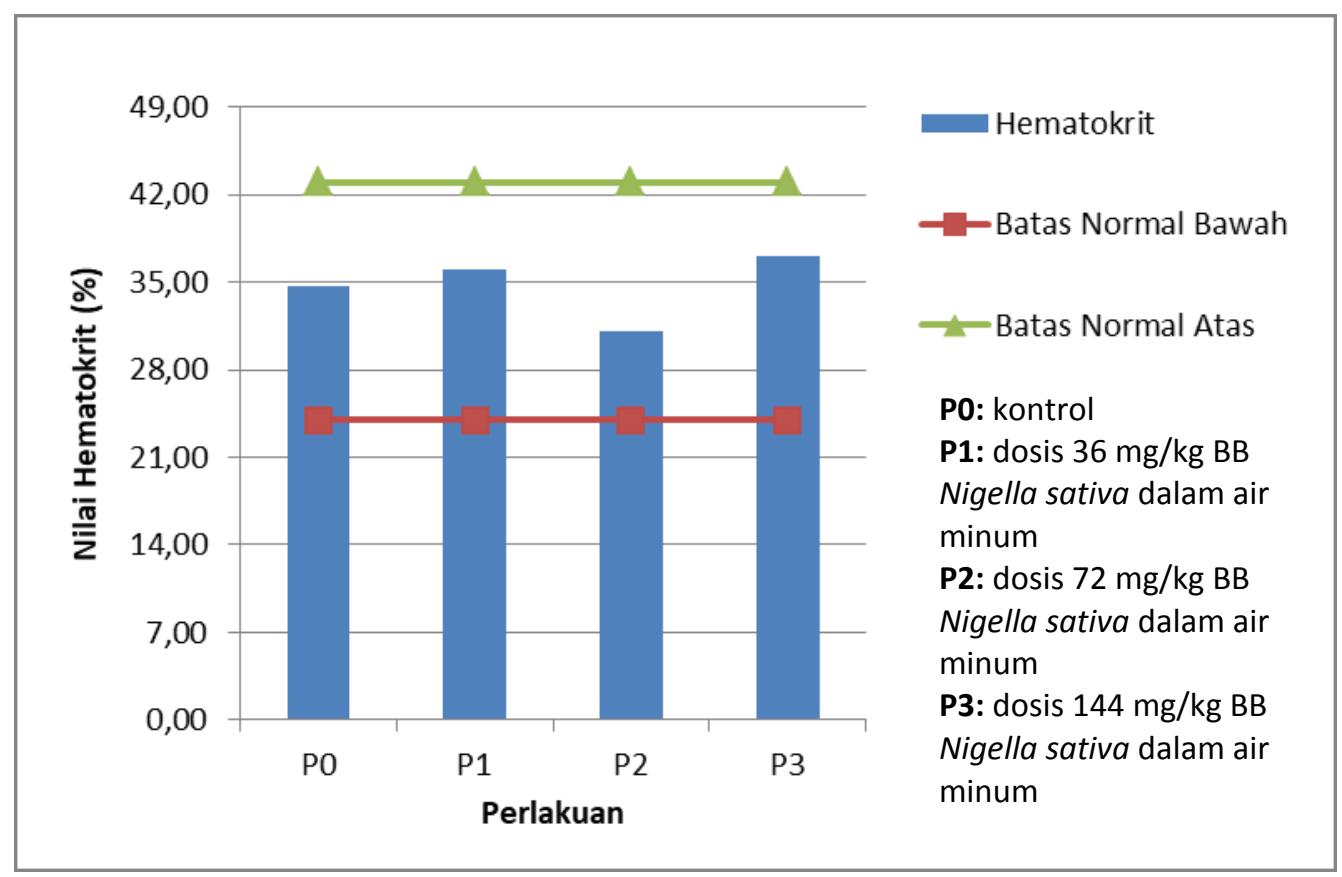

Gambar 2. Rata-rata nilai hematokrit broiler jantan

Pada perlakuan $\mathrm{P} 2$, terlihat bahwa nilai hemoglobin (Gambar 1) dan hematokrit (Gambar 2) lebih rendah dibandingkan perlakuan lainnya (P0, P1, dan P3) tetapi masih dalam nilai hemoglobin dan hematokrit normal. Hal ini diduga karena dosis $72 \mathrm{mg} / \mathrm{kg}$ BB kurang cocok pada penelitian ini dan peran imunomodulatornya tidak terlihat yang ditunjukkan juga dengan lebih rendahnya berat badan ayam pada perlakuan P2 dibandingkan perlakuan lainnya. Menurut Wagner (1990), beberapa hasil penelitian tentang imunomodulator bahan alami, dilaporkan bahwa pada dosis tertentu senyawa uji dapat meningkatkan sistem imun (imunostimulator), tetapi pada dosis yang berbeda dapat menurunkan sistem imun (imunosupresor).

\section{KESIMPULAN DAN SARAN}

\section{Simpulan}

Pemberian jintan hitam dengan dosis $144 \mathrm{mg} / \mathrm{kg}$ BB/hari (P3) merupakan dosis yang optimal untuk meningkatkan kadar hemoglobin dan nilai hematokrit dari broiler jantan.

\section{Saran}

Perlu adanya penelitian lanjutan tentang pemberian Nigella sativa (jintan hitam) pada broiler jantan dengan dosis yang lebih tinggi dan memperpanjang lama pemeliharaan dengan waktu pengambilan sampel minimal 3 kali selama pemeliharaan.

\section{DAFTAR PUSTAKA}

Bratawidjaja, K. G. 2006. Imunologi Dasar. Edisi 7. Balai Penerbit FKUI. Jakarta.

Dharmawan, N. S. 2002. Pengantar Patologi Klinik Veteriner (Hematologi Klinik). Cetakan ke-2. Pelawa Sari. Denpasar.

Guyton, A.C. and J. E. Hall. 2006. Textbook of medical physiology. 11 th ed. Elsevier Saunders. Philadelphia.

Hoffbrand, A. F. dan J. E. Pettit. 1996. Kapita Selekta Hematologi. Ed ke-2. Alih Bahasa: Iyan D. Penerbit Buku Kedokteran, EGC. Jakarta.

Muchacka, R., I. Skomorucha, E. S. Czajka, G. Formicki, A. Gren, and Z. Goc. 2012. Effect of elevated air temperature on physiological indicators of broiler chickens of different origin. $J$. Microbiology, Biotechnology and Food Sciences. 2 (1): 378-388

Narendra, D.W. 2007. Pengaruh Dehidrasi dengan Pemberian Bisa Codyl Terhadap Gambaran Hematokrit Tikus Putih Jantan (Rattus Norvegicus). Skripsi. Institut Pertanian Bogor. Bogor.

Patil, S. H., P. V. Deshmukh, , S. A. Sreenivas, V. Sankeertana, V. Rekha, and B. 
Anjaiah. 2012. Evaluation of anthelmintic activity of uncaria gambier roxb. against pheretima posthuma. J. Drug

Development and Research. 4: 234-238.

Praseno, K. 2005. Respon eritrosit terhadap perlakuan mikromineral $\mathrm{Cu}, \mathrm{Fe}$ dan $\mathrm{Zn}$ pada ayam (Gallus gallus domesticus). J. Indo. Trop. Anim Agric. 30 (3):179-185

Samour, J. 2015. Diagnostic Value of Hematology in Clinical Avian Medicine. Volume II. Harrison GJ, Lightfoot TL. Spix Publishing. Florida.

Siswanto. 2017. Darah dan Cairan Tubuh. Diktat Fisiologi Veteriner 1. Universitas Udayana. Denpasar.

Spelman, K., J. J. Burns, D. Nihols, N. Winters, S. Otterberg, and M. Tenborg. 2006. Modulation of cytokine expression by traditional medicines: a review of herbal immunomodulator. Alternative medicine review. 2 (2):128-150.

Sturkie, P. D. 1998. Avian Physiology. 5th Edition. Springer Verlag, New York.

Sudewo, B. 2012. Basmi Kanker Dengan Herbal. Visi Media Pustaka. Jakarta.

Syaodi, N. 2012. Metode Penelitian Pendidikan. PT Remaja Rosdakarya. Bandung.

Wagner, H. K. M. 1990. Immunostimulants and adaptogens from plants. $J$. Phytochemistry of Medical Plants. 29: 118 